\title{
Becoming QueEr Here: Integration AND AdAPTATION EXPERIENCES OF Sexual Minority Refugees in TORONTO
}

\author{
DAVID AB Murray \\ Associate Professor, York University
}

\begin{abstract}
Since the early 1990s Canada has become a primary destination for individuals who make refugee claims on the basis of sexual orientation persecution. However, until recently, there was little research focusing on this growing component of Canadian urban queer communities and their experiences of the refugee claim process, and their integration and adaptation to Canadian society. This paper, based on interviews with lesbian, gay, bisexual and transgender (LGBT) refugee claimants and participation in LGBT newcomer support groups in Toronto, explores the formal and informal processes, spaces and practices through which LGBT refugee claimants learn about the Canadian nation-state, citizenship and queer identities and communities, and in so doing enter a space/moment of becoming a 'becoming' refugee as they learn the social, cultural, and bureaucratic processes and norms of the Canadian refugee apparatus.
\end{abstract}

\section{Résumé}

Depuis le début des années 1990, le Canada est une destination de choix pour les personnes faisant des demandes d'asile en raison de persécutions basées sur l'orientation sexuelle. Toutefois, jusqu'à récemment, peu de recherche se sont penchées sur cette proportion grandissante des communautés urbaines allosexuelles canadiennes, sur leurs expériences du processus de demande d'asile, et sur leur intégration et leur adaptation à la société canadienne. Basé sur une série d'entrevues avec des homosexuels - hommes et femmes, des bisexuels et des transgenres (LGTB) demandeurs d'asile, et sur une participation dans les groupes de soutien aux nouveaux arrivants allosexuels à Toronto, cet article explore les processus formels et informels, les espaces et les pratiques par lesquels les demandeurs d'asile allosexuels se renseignent sur l'État, la nation et la citoyenneté canadiennes, ainsi que sur les identités et les communautés allosexuelles. Cet article examine également comment ces demandeurs d'asile deviennent, ce faisant, des réfugiés alors qu'ils apprennent quels sont les normes et les processus sociaux, culturels, et bureaucratiques du système canadien pour les réfugiés.

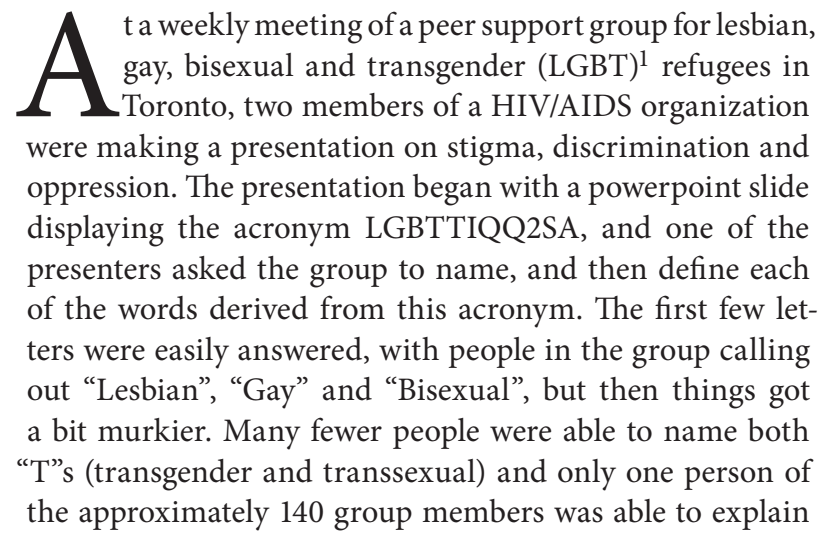


what "I" stood for (Intersex). "Queer" was named by a few, but "Questioning" was unknown by all (including me) "2S", (two spirits), was recognized by a few, but "A", (Allies) appeared to be another new label for most people in this group. Following this exercise, one of the presenters handed out sheets of paper with the question, "When I hear (blank space) I know I am being discriminated as a LGBTTIQQ2SA" written at the top. He then asked people to say what they wrote down so he could create a list on a whiteboard at the front of the room, and the group quickly came up with a long list of mostly derogatory terms for homosexuals in different societies: chichiman, battyman, fish (Jamaica), pede (Cameroon), makoume, zame, and sewer rat (St Lucia), koni (Iran/Persian), shoga and moffee (Kenya), kuchu (Uganda) sodomite, onisan (Nigeria). The group was much more lively for this portion, and as some words were named, there was laughter and giggling from other group members who were presumably from the same country or language area. The list got longer and longer, and the group became increasingly animated until the presenter had to ask some people to stop laughing as these terms could be very hurtful to others in this group.

These two adjoining moments, one of relative silence, and another of boisterous noise, which took place during a conversation about naming sexual identities and discriminatory words in different socio-cultural contexts, involving people who have migrated to Canada from multiple countries and who are currently in the process of applying to be a convention refugee on the basis of sexual orientation perse cution, encapsulated, for me, some of the complexities of the process of becoming a 'sexual minority refugee' in Canada. In this paper I want to explore the idea and work of 'becoming' a sexual minority refugee. In so doing, we might begin by exploring the meaning of the word becoming, which operates as both adjective and noun: As a noun, becoming is defined as 'any process of change', or as an element of Aristotelian philosophy, that is, "any change involving realization of potentialities, as a movement from the lower level of potentiality to the higher level of actuality". 2 This definition fits quite nicely with the sexual minority refugee claimant, as few arrive in Canada thinking of themselves as 'refugees', and some do not think of themselves as members of a particular sexual minority identity group, or at least do not recognize and identify with sexual minority identities as they are defined and organized in Canada. However, in the period leading up to their Immigration and Refugee Board (IRB) hearing, the sexual minority refugee claimant must learn relatively quickly how to 'be' or at least 'occupy' these identities, as the hearing is usually dedicated to assessing the credibility of the claimant as a member of a particular social group who has faced persecution in their country of origin. In other words, they must prove they are who they say they are and that they have faced hardships based on this identity that meet a standard definition of persecution. They are reminded repeatedly by their lawyers, peer support group leaders and each other that there are a number of components, characteristics and assumptions utilized by IRB Members to determine credibility as a sexual minority refugee, and that if they understand these assumptions and characteristics, then they stand a better chance of a successful hearing. Thus all refugee claimants are incommensurate or potentialities until their hearing, which we might think of as a test of actualization or commensurability ${ }^{3}$ in which some do very well, and some do not.

If we think about the hearing as an 'actualization or commensurability test' in which the refugee claimant is trying to convince the Board Member of her credibility as a member of a particular social group suffering from persecution, then I think it is also useful to think about 'becoming' as an adjective, in which it is defined as, 'suitable; appropriate; proper ... that suits or gives a pleasing effect or attractive appearance, as to a person or thing, as in a becoming dress'. At the hearing, the refugee claimant is relegated to a position in which they must do everything they can to 'give pleasing effect' to convince the Board Member they are who they say they are as the Board Member has the power to make a final decision on the veracity of this individual's claim. Once again, in refugee support group meetings, conversations between refugees and their lawyers, and amongst refugee claimants themselves, there is a mostly implicit, sometimes explicit understanding of the importance of becoming a 'becoming' refugee at one's hearing, and time and effort is dedicated to learning strategies and techniques that will ensure a successful performance. ${ }^{4}$

In this paper I explore a few of these moments where strategies and techniques of becoming a becoming sexual minority refugee are articulated and developed, based on my participation in these refugee support groups, interviews with refugee claimants and lawyers, and observations in a number of refugee hearings over the period of July 2011 to June 2012. In so doing, I hope to focus on some of the formal and informal processes, spaces, discourses and practices through which sexual minority refugee claimants in Toronto learn about, discuss and debate the terms through which they are defined within the structure of the immigration and refugee system in which they are located. I build on Malkki's observation that the refugee should not be taken as a naturally self delimiting domain of knowledge, and that the category of refugee is an epistemic object in construction $^{5}$. However, rather than analyzing the inequalities inherent in the production and structure of the episteme and the bureaucratic and legal system created around it, 
which is where I would locate the majority of recent research on LGBT refugees in Canada ${ }^{6}$, in this paper I focus on how the refugee claimant comes to understand the meaning of the episteme and system, obtains the knowledge to navigate this complex system, and in so doing learns to become a becoming LGBT refugee. This process of becoming also invokes particular incarnations of nationalism and citizenship, which are themselves freighted with moral valences of proper assemblages of sexuality, gender, race and class. I will therefore also unpack some of the embedded moral valences contained in the learning process of becoming a queer refugee. My objective is in line with recent queer and feminist studies that demonstrate how discourses and practices of gender and sexuality are critical to the maintenance of liberal and illiberal forms of power and domination and are at the governmental heart of capitalism, secularism, and civil society ${ }^{7}$.

More generally, I argue that learning about the relationship between one's own sexual desires and more widely circulating socio-sexual identity terminologies is a never-ending process for everyone due to multiple changing political, cultural and economic forces which continuously impact, undergird and transform those terminologies and their meanings. However, for the sexual minority refugee this process of learning is intensified through migration into a hyper-visible moment of state scrutiny. There are four to five distinct moments or spaces in the life of a sexual minority refugee in which they voluntarily or involuntarily learn about, confront, reflect, and/or claim a particular socio-sexual identity: First, in their country of origin, they learn, as children and young adults, about 'queerness' in a local context, that is, how sexual diversity is viewed, evaluated, rewarded or penalized in their home town, city and country. For those who grow up in urban areas, and/or who have access to electronic communications technologies that provide access to 'foreign content', such as international films, videos, and other media, and the internet, or for those who live in areas where people from 'outside' nations or cultures come to visit, work or live, there is often a second space or moment of learning, in which they read about, encounter, or see images of people who engage in similar sexual activities, but who look, sound and behave differently and utilize a language that makes different associations between those similar sexual practices and identity formations. The third moment/space of learning for a sexual minority refugee begins just after they arrive at Pearson airport or enter the offices of the Citizenship and Immigration Canada in suburban Toronto and submit their application for refugee status. From this moment on, the individual must learn about 'becoming a becoming' LGBT refugee as I outlined above. This is perhaps the most hyper-visible, self-conscious and deliberative period due to the refugee's tenuous position in a system in which the state now scrutinizes their past sexual behavior in order to assess whether that behavior fits a particular definition of sexual identity, and if so, whether that sexual identity is subject to persecution in the individual's country of origin. The fourth moment/space of learning often occurs simultaneously alongside the third; this is the process of learning about how sexual diversity is organized, named and located in their new surroundings, in this case, metropolitan Toronto. This learning occurs partially in the refugee support group meetings and interactions with their lawyers and other groups associated with the refugee settlement process, but it also occurs through everyday experiences of the refugee on public transit, while shopping, in their jobs and in their accommodations and surrounding neighbourhoods. The fifth and final moment/space occurs after a successful hearing ${ }^{8}$, in which the now 'official' convention refugee can begin to apply for permanent resident status in Canada, and can make plans for their future envisioning themselves as a potentially full Canadian citizen without fear of deportation. The state's hyper-scrutinization of the convention refugee's sexual orientation retreats (but never completely disappears), and the individual may adjust their sexual desires and practices to identities and behaviours that they are more familiar with; for some this may entail very little change from their pre-hearing life; for others, there may be adjustments that align with their own personal comfort levels and past experiences, and/or which are made in relation to other factors like jobs, family, romantic relationships and community support networks.

Each of these five space/moments merits an individual paper, given their complex locations and differential intensities for anyone who goes through the sexual minority refugee process; in the remainder of this paper I focus on the third space/moment which begins after the refugee claim has been submitted and ends at the hearing, in which the work of 'becoming' is most intense, and becoming is, in a sense, doubled or possibly trebled, as an individual is not only learning about sexual, gendered and other identity formations in their new society, but they are also learning about how IRB members will think about and assess the 'credibility' of their membership in a particular social group (i.e. their sexual orientation), and they are learning the criteria required to meet the definition of 'refugee'. I will argue that this space/moment of becoming a becoming LGBT refugee is similar to Povinelli's observations on the effects of multicultural domination of indigenous subjects in Australia, which works by inspiring subaltern/minority subjects to identify the with the impossible object of an authentic self-identity. ${ }^{9}$ 
In their article examining issues that arise in eliciting and presenting a refugee narrative when the claim is based upon sexual orientation, Berg and Millbank note that the narrative must be presented as comprehensively as possible early in the claim process because the requirement of consistency of later testimony is a significant feature of refugee adjudication. Sexual orientation refugee claimants face additional challenges because much of the adjudication is based on the personal narrative of the applicant; unlike claims based on political opinion, race, nationality or religion, which more commonly have some form of independent verification of group membership, sexual orientation claims depend mostly on the presentation of internal, often unspoken, or unspeakable qualities, desires, and practices such that extremely private experiences infuse all aspects of the claim ${ }^{10}$. Furthermore, "in the refugee context, it is always the decision maker and not the applicant who has the power to name, the authority to decide who the applicant 'really' is and what sexuality 'really' means"11. Berg and Millbank reveal how adjudicators often apply their own understandings of sexual identity based on a staged model of sexual identity development which is based upon specific cultural, gendered, raced and classed experiences and operates with particular assumptions about sexual identity as fixed, discoverable, and moving from a position of closeted to 'coming out', in which the hearing serves as the apotheosis to this narrative ${ }^{12}$.

The determination of credibility in sexual minority refugee cases is further complicated when this staged model of sexual identity development is applied to racialized bodies. Most of the refugee claimants I interviewed were from Caribbean or African nation-states and upon arriving in Toronto came to be identified as a 'visible minority' in addition to being a sexual minority. As numerous scholars have noted, the 'black' body is always/already doubted or debated in North American mainstream (white) LGBT discourses based on assumptions about 'down low' (hidden homosexual) practices and 'macho' black masculinities that are problematically classified as homophobic ${ }^{13}$. Doubt or disbelief is augmented when racialized bodies are also refugee bodies: These 'visible minorities', are seeking state protection (and eventually citizenship) based on their claim to being queer and persecuted, but their claims are judged, evaluated and scrutinized through racialized lenses in everyday settings as well as every step of the way through the refugee process, from the Canadian Border Services Agency officers at the airport, to support group volunteers to fellow refugee claimants and finally to the IRB Members. Some of this suspicion may be generated through cross-cultural mis-translations (which are then linked to racialized stereotypes) but I would argue suspicion is more profoundly generated through the racialized, gendered, and classed hierarchies and normativities that undergird the structure of the refugee system itself.

When differential understandings of self and sexual desire come into contact with a state apparatus that requires explicit declaration and proof of a particular (i.e. racialized, gendered, and classed euro-american) sexual identity formation in order to grant protected refugee status, the potential for misinterpretation, and in turn, accusations of 'false claims' are all the more likely. All queer claimants are negotiating culturally proscribed identity narratives before, during and after their hearings, and in the struggle to make hidden, invisible and/or highly personal aspects of the self visible to adjudicators, support workers, volunteers and other queer migrants in an environment built upon the exclusionary process of determining an authentic refugee, the challenge to prove one's credibility as a member of the LGBT social group is heightened for those whose racialized identities are associated with 'problematic' sexualities or attitudes towards sexual diversity.

While Berg and Millbank and others point out the numerous and profound problems inherent in applying a staged model of sexual development' to adjudicate sexual minority refugee narratives, I think it is important to note that many of the refugee claimants I worked with were not entirely naïve about this model and other components of the adjudicating process, and that they spent a great deal of their time and energy learning about the structure and process of the hearing, and what was necessary to ensure that they would appear as 'credible' and 'authentic' both in their file and at the hearing. In other words, the refugee claimants were actively engaged with the system in which they had been placed and exercised agency in their efforts to meet or fit into these assumed standards of evaluation (albeit to greater or lesser degrees depending on the individual claimant).

I now present a couple of discussions and events which serve as examples of how refugee claimants learn and experience the space/moment of becoming a becoming refugee. The first example is a set of comments made by a refugee lawyer during her presentation to an LGBT refugee support group, and the second comes from discussions with two refugee claimants about preparing for their hearings.

At the refugee support group meetings I attended, a number of immigration and refugee lawyers were invited by the facilitator to speak to the group about the refugee process in Canada, preparing for the hearing, and obtaining and working with legal counsel. The visiting lawyers often received the unbroken attention from everyone in the group, as opposed to other presentations that focused on banking or finding accommodation, in which I could see quite a few people texting on their cellphones, or quietly whispering to 
each other. Of the four lawyers that I heard speak to the group, each had a significantly different presentation style, with some using anecdotes from hearings they attended to get across their point, and others using power point presentations that contained United Nations Refugee Convention and Protocol definitions and concise lists of what to do and not to do in preparation for a hearing. One lawyer who spoke to the group combined power point slides and a presentation style which a couple of group members noted afterwards was similar to a drill sergeant addressing his troops. The lawyer began by providing the group with a timeline of the refugee claim process, and spent a fair amount of time focusing on the Personal Information Form (PIF), which every claimant must fill out and submit to the IRB within 28 days of making their claim. The most important part of the PIF, she said, is the narrative, "which is where you tell your story", but she then recommended getting a lawyer, "to help make sure it's your own voice." She then provided some insight on the purpose of the PIF and some strategies on how to write it: "When the Board Member gets the story they want to relate the story to the person; the PIF must be in your own voice, it doesn't matter if there are grammatical errors ... If the story is too much like a $\mathrm{PhD}$ and you only have a grade 5 education, that creates doubt." This comment had some group members laughing. Furthermore, she went on, the PIF must be synchronized with all the other documents that are submitted-i.e. letters from family, lovers and friends, hospital and police records, school transcripts, etc. She then advised, "to take out things that will negatively impact you; if someone who doesn't really know you writes a letter or says something that's not right, take it out". She continued,

From the day you put in your PIF, your PIF is your bible, like a book you keep close to you; you read it every day; your life depends on it. If you ignore it you could lose your life ... Read read read read read your narrative. Put yourself in the mind of the judge: How would you make him believe you? What do I need to show that I have same sex partner or friend? If I was punched and kicked and then ran to a friend's house, what is my friend's name? What time of day did this happen? What's the distance between the houses? You have to pre-empt the judge.

The lawyer also commented on the importance of refugee claimants knowing legal definitions:

You should know the legal definition of a "Convention Refugee": You must demonstrate that you cannot return to your country of origin; that there is serious risk to your life, based on membership of a particular social group-sexual orientation, race, religion, nationality, political opinion all qualify as membership categories
... Canada can't save everybody, you can't come claiming that everyone is poor back in Burundi and its hard to get a job."

The personal narrative component of the PIF generated a lot of discussion amongst refugee claimants. Whether they learned about its importance from their lawyers, each other or reading guidelines on the IRB website, the personal narrative was recognized as the central document around which their claim would be built and assessed by the Board Member. Even though claimants at the support group meeting were told by the lawyer that the PIF 'is where you tell your story', the lawyer immediately followed this statement by recommending that they get a lawyer 'to help them tell their story', but didn't elaborate at that moment as to why someone would need help in telling their own story or what kind of 'help' is needed. However, claimants quickly learn that the personal narrative is not simply a matter of telling their 'life story', and that there is a particular structure or framework to this narrative, and that it must include important features or components that address the jurisprudential objective of determining the credibility of a refugee claim. In other words, the personal narrative becomes a document that is viewed as evidence given by the claimant about his or her claim, and that evidence is evaluated in relation to other documents and the testimony of the claimant at the hearing. So even though the lawyer told the group that the PIF must be 'in your own voice', she went on to provide some specific examples of what that voice should comment on or include, i.e. a friend's name, the distance between the house you were punched in and your friend's house, the time of the day at which the violence took place. These are elements of a very particular kind of storytelling, one that fits the parameters of a courtroom in which facts are elicited and tested in order to determine the truth or falseness of a defendant's claim. In other words, the personal narrative is located within and structured by the formulism and formalism of western juridical concepts and processes. ${ }^{14}$

Not surprisingly, listening to presentations like that of the lawyer can stir up anxiety amongst refugee claimants. Ruth, who is in her 50 s, from St. Lucia ${ }^{15}$, and who self identifies as lesbian, said that the whole PIF process was nerve-wracking, because after she wrote and submitted it to her lawyer, she remembered things that had happened to her that she thought were significant. She said, "there were things you try to forget, or your mind blocked because it didn't want to remember them, but they come back suddenly, maybe even when you're being asked a question." For example, after she submitted her PIF to her lawyer she remembered an incident where she'd been driving her car, and as she passed a man he yelled 'sodomite' and threw a rock at her. She remembered hearing the window glass break, and felt a bit of the 
glass hit her, but thought she was ok and drove on, until at a stop sign a woman in another car looked over and told her there was blood coming down the side of her face. She ended up needing two stitches for this. But since it wasn't in her PIF, she wasn't supposed to talk about it. "It's this kind of business that can lead to confusion", she added.

Shawn, who is in his 20 s and from Grenada, had met with his lawyer a couple of times to discuss his PIF and how he would be questioned at the hearing. In one of our interviews, he discussed these conversations with his lawyer: David: Did (your lawyer) say that the Board Member probably will ask questions like, which day were you attacked?

Shawn: Well, the way he said, it's like, 'What happened on June the 22nd, 2010' and I'm supposed to describe what happened. So, you don't want to confuse June 2010 with June 2009.

David: Right ... I have heard some people say that they know what happened to them, but when they're in the hearing they're nervous because everybody is looking at you, so it's sometimes hard to remember the dates... . Do you feel like you have to rehearse it to yourself?

Shawn: Yes, I think it reduces the anxiety of it, because I'm used to studying for exams. So, it is an exam that I have to study for.

Shawn had learned from his lawyer that his PIF would become a piece of evidence from which he would be asked questions about 'the facts' in his hearing in order to corroborate his written testimony. Shawn realized that the PIF was a particular kind of story-telling in which certain events, dates, locations and names would form the central line of questioning at the hearing, so he was now approaching it like an exam that he needed to study for. For Shawn, this was not too scary as he was a university student and said he was used to studying for tests. Shawn had also discussed the PIF and other aspects of preparing for the hearing with other refugee claimants. From these discussions, he had learned of the importance of submitting other documents to help strengthen his case, such as media coverage of homophobic events in Grenada.

David: Do you get, do you share with other refugees when you find good articles or good information, about things back in Grenada, do you share that?

Shawn: Well, Marvin (another refugee who had recently had a successful hearing) would do that, because he went through it. And he loves to do that. So, he would say, Shawn here's an article related to your case. I would read it and I would say, okay this is related or no it's not related. And there are times when I would say to a friend who is going through the refugee claim, 'Here's an article on gay (issues) ... you might want to take a look at it. I'm not sure if it's related to your case, but you can take a look at it to see if it's related, yes or no.

In this conversation, Shawn demonstrates his knowledge of the definition of a 'convention refugee' and the IRB hearing structure (thus reinforcing the advice the lawyer gave in her presentation) in that he knows that there must be evidence presented to the Board Member to demonstrate that members of the particular social group that he belongs to face persecution in their country of origin. Through his conversations with other refugees like Marvin who have gone through the process, he was now scanning Grenadian newspapers online and printing out any articles that dealt with gay issues. Shawn felt that the more articles he could find and submit to his lawyer (who would forward them to the IRB as part of his documentation file), the more he would strengthen his chances of a successful hearing. In this case, Shawn knew that his narrative was not enough, and that additional evidence was required in order to meet the criteria of being not just LGBT but an LGBT 'refugee'.

These snippets from presentations and conversations by differentially positioned individuals in the particular space/ moment of becoming a becoming LGBT refugee resonate with Povinelli's observations on the effects of multicultural domination of indigenous subjects in Australia, which works by inspiring subaltern/minority subjects to identify with the impossible object of an authentic self-identity. For indigenous peoples this is a 'traditional' form of society and subjectivity associated with an imagined past, but because they are in the present, and part of the present, they can never fully achieve this fantasy, so the multicultural nationalist is always disappointed, and the indigenous can never be really real ${ }^{16}$. The sexual minority refugee faces a similar challenge of identifying with the impossible object of an authentic LGBT self-identity. For the refugee, this is an essentialist form of socio-sexual identity that is associated with a normative Euro-American sexual identity formation, that is, a staged model of sexual identity development applied to one of 4 sexual identity categories (Lesbian, Gay, Bisexual or Transgender). The onus is on the refugee claimant, who often comes from a society that does not operate with this normative model, to prove to the Board Member that their documents, actions and statements, past and present, match this model. Furthermore, this socio-sexual identity must also be linked to a set of assumptions and beliefs attached the object identity of the 'authentic refugee'. Both of these 'impossible objects' are defined by past and present state legislation and policies, the past influenced by international legislation (such as the UNHCR Convention 
Relating to the Status of Refugees) and the present influenced by current national and/or regional political regimes. While it may be theoretically plausible (if not imperative) to contend that 'sexual' and 'refugee' identities are malleable, diverse and subject to transformation due to multiple intersecting social, political and economic forces, it is not in the interest of the Canadian refugee determination system to define or think about them in this way (perhaps it is not even possible). Thus, implicit (in the case of sexual identities) and explicit (in the case of refugee identity) definitions and assumptions are developed and applied by the IRB, whose responsibility is determining the credibility and authenticity of the claims of the persons before them according to a model based on western jurisprudential paradigms of determining truth.

As Carole McGranahan notes, for refugee claimants, "the truths they tell in asylum court rest on an always contingent set of situated realities: on state structures of asylum, on social knowledge of the process, on cultural understandings of how to narrate one's life, and on political discourses of truth, rights and hope"17. In this paper I have focused on some of the ways in which sexual minority refugee claimants gain social knowledge of the process and strategic understandings of different cultural logics of how to define one's sexual identity and narrate one's life. I have also tried to demonstrate that in the face of daunting challenges in which they must attempt to figure out and navigate a foreign legal and bureaucratic system with its complex and foreign terminologies, moralities and meanings that are designed to exclude as much as they are to include, many refugee claimants devote a great deal of time and energy into learning these new words and worlds, as they recognize that they must learn to present themselves and tell their stories in a certain way, and 'materialize' into a particular formation of sexual identity and refugeeness that matches the adjudicator's formalistic and formulistic definitions and juridical common sense ${ }^{18}$. Attending presentations on how to prepare for hearing given by refugee lawyers, participating in a session on stigma and discrimination which explains the words contained in the sexual identities acronym, or chatting with past refugee claimants about what documents matter, and how to build a stronger file, are examples of the agency of refugee claimants and an awareness of the structures and hierarchies into which they have been placed and must navigate in order to obtain a positive outcome. While there are clearly differing levels of engagement and awareness amongst refugee claimants, most of those whom I interviewed and listened to were constantly learning and working hard to become as becoming as possible.

From the moment they submit their refugee claim to the moment of the decision at their hearing, refugees exist in a space/moment of "incommensurability"19 a state of affective potential, in which the paradoxical yet unknown enters upon the world of norms, in this case the state's rules and regulations defining the 'proper' refugee, which now includes the sub-category of the 'proper' LGBT refugee. This space/moment of emergence or becoming is key to theorizing the pivot point between incommensurability and mandated commensuration. The emerging or becoming sexual minority refugee is akin to the introduction of an incommensurability into social life, the latter defined through the regulation and operation of intersecting sets of norms ${ }^{20}$. The LGBT refugee claimant quickly learns that they are an unknown quantity in the eyes of the Board Member, and that they will be judged according to a pre-existing set of criteria to determine whether or not they have the state's approval (and all the rights and privileges that go with it) to be identified as a 'convention refugee'. Massumi takes "emergence" as a bifurcation point in which multiple and normally mutually exclusive potentials coexist but from which only one can be chosen ${ }^{21}$. However, the emergence of a sexual minority refugee is marked by a constitutive overdetermination: despite the deeply diverse social, sexual and migration experiences of these individuals, an already existing set of socio-sexual-political classifications of the destination state forces closure of potential through its commensuration with existing norms.

The presentations and conversations focusing on PIFS, LGBTTIQQ2SAs, and other IRB hearing related topics amongst refugee claimants, lawyers and support workers illustrates how "the asylum process rests not only on law but also on the limits of humanity, of how humans treat each other, and on the very grey, often painful space between creativity and vulnerability" 22 Becoming a becoming sexual minority refugee is a process that involves creativity, intense learning, and rapid adaptation to a new set of terms, ideas and norms about the relationship of one's sexual practices and desires to the socio-political world in which they are rendered sensible. The creative and adaptive potential of the refugee claimant, along with the knowledge and skills of their lawyer and their support group facilitators, are crucial components of a successful refugee hearing. However, the stakes are high and stacked against them, as the nervous state continuously works to manage and control migration, and in particular the movement of refugees who are increasingly viewed as illegal interlopers until proven otherwise. ${ }^{23}$

\section{REFERENCES}

Berg, Laurie and Jenni Millbank 
2009 Constructing the Personal Narratives of Lesbian, Gay and Bisexual Asylum Claimants. Journal of Refugee Studies 22(2):195-223.

Dave, Naisargi N.

2011 Indian, Lesbian and What Came Next: Affect, Commensuration and Queer Emergences. American Ethnologist 38(4):650-65.

Feldman, Gregory

2012 The Migration Apparatus: Security, Labor, and Policymaking in the European Union. Stanford: Stanford University Press.

Ferguson, Roderick

2004 Aberration in Black: Toward A Queer of Color Critique. Minnesota. University of Minnesota Press.

Johnson, E. Patrick and Mae Henderson (eds)

2005 Black Queer Studies: A Critical Anthology. Durham: Duke University Press.

Johnson, Toni a.m.

2011 "On Silence, Sexuality and Skeletons: Reconceptualizing Narrative in Asylum Hearings". Social and Legal Studies 20(1):57-78.

Jordan, Sharalynn

2010 "Un/Convention(al) Refugees: Contextualizing Accounts of Refugees Facing Homophobic or Transphobic Persecution". Refuge 26:2 (165-82).

Lewis, Rachel

2010 "The Cultural Politics of Lesbian Asylum" International Feminist Journal of Politics 12(3-4):424-43.

Malkki, Liisa

1995 'Refugees and Exile: From 'Refugee Studies' to the National Order of Things". Annual Review of Anthropology 24:495-523.

Manalansan IV, Martin F

2009 Homophobia at New York's Gay Central. In Homophobias: Lust and Loathing Across Time and Space. David AB Murray, ed. Durham: Duke University Press.

Massumi, Brian

2002 Parables for the Virtual: Movement, Affect, Sensation. Durham, NC: Duke University Press.

McGranahan, Carole

2012 "Anthropology and the Truths of Political Asylum, Part II". Anthropology News 53(4):20-21.

Murray, David A.B.

2002 Opacity: Gender, Sexuality, Race and the 'Problem' of Identity in Martinique. New York: Peter Lang Press.

2009 (editor) Homophobias: Lust and Loathing Across

Time and Space. Durham: Duke University Press.

Ou Jin Lee, Edward and Shari Brotman

2011 "Identity, Refugeeness, Belonging: Experiences of Sexual Minority Refugees in Canada". Canadian Review of Sociology 48:3 241-74.

Povinelli, Elizabeth

2001 Radical Worlds: The Anthropology of Incommensurability and Inconceivability. Annual Review of Anthropology 30:319-34.
2002 The Cunning of Recognition Indigenous Alterities and the Making of Australian Multiculturalism. Durham: Duke University Press.

2006 The Empire of Love. Durham: Duke University Press.

\section{Notes}

1. These are the sexual identity categories utilized by the group in its title. In this article I utilize sexual identity terminologies as they articulated by organizations, individuals and as they appear in texts. As they are articulated by this article and other research on sexual minority refugees demonstrates, all sexual identity terminologies are fraught with historical, political and cultural specificities, which are heightened and intensified when inserted into the bureaucratic and juridical machinery of the immigration and refugee determination system.

2. www.dictionary.com, accessed April 9, 2012.

3. Elizabeth Povinelli, "Radical Worlds: The Anthropology of Incommensurability and Inconceivability," Annual Review of Anthropology 30 (2001):319-34.

4. At the same time, these meetings and conversations are never just strategic planning sessions; they are also complex sites of trans-cultural learning about multiple aspects of living in Canada and about the differences and similarities between people from diverse backgrounds. They are also sites of socializing with other refugee claimants and members of the queer community in Toronto, where gossip, flirting, and commiseration over the daily challenges of adapting to life in a new place are exchanged.

5. Liisa Malkki "Refugees and Exile: From 'Refugee Studies' to the National Order of Things", Annual Review of Anthropology 24 (1995):495-523.

6. For example, see Laurie Berg and Jenni Millbank, "Constructing the Personal Narratives of Lesbian, Gay and Bisexual Asylum Claimants," Journal of Refugee Studies 22 No. 2 (2009):195-223; Toni a.m. Johnson, "On Silence, Sexuality and Skeletons: Reconceptualizing Narrative in Asylum Hearings," Social and Legal Studies 20 No.1 (2011):57-78; Sharalynn Jordan, "Un/Convention(al) Refugees: Contextualizing Accounts of Refugees Facing Homophobic or Transphobic Persecution," Refuge 26 No. 2 (2010):165-82; Rachel Lewis, "The Cultural Politics of Lesbian Asylum" International Feminist Journal of Politics 12 No. 3-4 (2010):424-43; Edward Ou Jin Lee and Shari Brotman, "Identity, Refugeeness, Belonging: Experiences of Sexual Minority Refugees in Canada," Canadian Review of Sociology 48 No. 3 (2011):241-74.

7. Elizabeth Povinelli, The Empire of Love. (Durham: Duke University Press, 2006), 12-13.

8. For those who 'fail' their hearing, the fourth moment/ space intensifies as the claimant seeks other legal/bureaucratic solutions to prevent deportation, all of which involve ongoing surveillance and evaluation by state authorities. 
9. Elizabeth Povinelli, The Cunning of Recognition Indigenous Alterities and the Making of Australian Multiculturalism (Durham: Duke University Press, 2002).

10. Berg and Millbank, 196.

11. Ibid., 208.

12. Ibid., 207-15.

13. Roderick Ferguson, Aberration in Black: Toward A Queer of Color Critique (Minnesota. University of Minnesota Press, 2004); Patrick E. Johnson and Mae Henderson, eds, Black Queer Studies: A Critical Anthology, (Durham: Duke University Press, 2005); Martin F Manalansan IV, "Homophobia at New York's Gay Central" in Homophobias: Lust and Loathing Across Time and Space, ed. DAB Murray (Durham: Duke University Press, 2009); David A.B. Murray, Opacity: Gender, Sexuality, Race and the 'Problem' of Identity in Martinique (New York: Peter Lang Press, 2002); David A.B. Murray, ed. Homophobias: Lust and Loathing Across Time and Space, (Durham: Duke University Press, 2009).

14. T. Johnson, 62.

15. Names and identifying details of all research participants have been changed in order to ensure anonymity.

16. Povinelli (2002), 6-7.
17. Carole McGranahan, "Anthropology and the Truths of Political Asylum, Part II”, Anthropology News 53 No.4 (2012):20-21.

18. Ou Jin Lee and Brotman, 249.

19. Povinelli, 2001.

20. Naisargi Dave, "Indian, Lesbian and What Came Next: Affect, Commensuration and Queer Emergences" American Ethnologist 38 No. 4 (2011):650-65.

21. Brian Massumi, Parables for the Virtual: Movement, Affect, Sensation (Durham: Duke University Press, 2002):32-33

22. McGranahan, 22.

23. Gregory Feldman, The Migration Apparatus: Security, Labor, and Policymaking in the European Union (Stanford: Stanford University Press. 2012).

David AB Murray is author of the book, "Flaming Souls: Homosexuality, Homophobia and Social Change (University of Toronto Press, 2012) and "Homophobias: Lust and Loathing Across Time and Space" (Duke University Press, 2009). He is a member of the Department of Social Anthropology and Sexuality Studies Program at York University.

(C) David AB Murray, 2011. This open-access work is licensed under a Creative Commons Attribution-NonCommercial 4.0 International License, which permits use, reproduction and distribution in any medium for non-commercial purposes, provided the original author(s) are credited and the original publication in Refuge: Canada's Journal on Refugees is cited. 